\title{
HABILITAÇÃO PRELIMINAR NAS LICITAÇÕES
}

\author{
REINALDO MOREIRA BRUNO*
}

\begin{abstract}
1 - Considerações gerais; 2 - Conceito e finalidades; 3 - Princípios regentes da licitação; 3.1 - Princípio da Isonomia; 3.2 - Procedimento Formal; 3.3 - Publicidade; 3.4 - Sigilo na Apresentação das Propostas; 3.5 - Vinculação ao Edital; 3.6 - Julgamento Objetivo; 4 - Habilitação prevista no artigo 27, l a VI; 4.1 - Habilitação Jurídica; 4.2 - Qualificação técnica; 4.3 - Qualificação econômico-financeira; 4.4 - Regularidade fiscal; 4.5 - Regularidade previdenciária e fundiária; Bibliografia
\end{abstract}

\section{1 - Considerações gerais}

Em geral, a realização de licitação constitui-se antecedente obrigatório e necessário dos contratos administrativos, materializado mediante procedimento administrativo, de natureza meramente preparatória, ensejando ao final deste, expectativa de direito ao vencedor.

Na hipótese de o contrato vir a ser celebrado, este o será apenas e tão-somente com o vencedor deste procedimento que visa selecionar a melhor proposta para atender aos interesses da Administração.

A Constituição Federal impõe sua realização a partir do disposto no artigo 37, $\mathrm{XXI}$, e ainda reserva à União competência privativa para legislar sobre regras gerais, nos termos do artigo 22, XXVII.

No exercício desta competência, veio a União editar a lei 8.666 em 21 de junho de 1993, alterada pelas leis 8.883/94, 9.032/95 e 9.648/98 que aplicam-se à Administração Direta, Indireta e Fundacional, enfim, a todo o Poder Público, restando aos demais entes e esferas legislar supletivamente sem, porém, afrontar as disposições daquela.

* Advogado, Mestre em Direito, Professor da Cadeira de Direito Administrativo da Unimes e Unimonte, ambas em Santos-SP. 


\section{2 - Conceito e finalidades}

Para o saudoso Hely Lopes Meirelles', licitação, constitui-se em " procedimento administrativo mediante o qual a Administração seleciona a proposta mais vantajosa para o contrato de seu interesse".

Já Maria Silvia Zanella Di Pietro ${ }^{2}$ ao referir-se a este instituto, assim o conceitua "como o procedimento administrativo pelo qual um ente público, no exercício da função administrativa, abre a todos interessados, que se sujeitem a condições fixadas no instrumento convocatório, a possibilidade de formarem propostas dentre as quais selecionará e aceitará a mais conveniente para a celebração de contrato."

Caracteriza, basicamente, este processo seletivo de melhor proposta:

- constituir-se em sucessão ordenada de atos administrativos;

- propiciar igualdade entre os interessados no futuro ajuste com a Administração; e

- promover a vinculação entre as partes, Administração e o particular.

Nos termos do artigo $3^{\circ}$ "caput" da Lei $n^{\circ} 8.666 / 93$ e suas alterações posteriores, encontram-se positivados como características básicas:

- Princípio constitucional da Isonomia;

- Seleção da proposta mais vantajosa para a Administração.

A partir destes aspectos, é possível constatar que encontra-se implícito nesta associação de princípios o conceito de competitividade, que é da própria essência do instituto, pois é de presumir-se que os interessados concorrerão entre si, para oferecer a melhor proposta para a Administração.

Impõe ressaltar que não visa tão-somente o menor preço (apenas uma das modalidades de julgamento previstas no artigo 45 da Lei 8.666/93) e sim, selecionar a menor proposta dentre aquelas habilitadas, ou seja, que atenderem as exigências do instrumento convocatório (edital ou convite).

\section{3 - Princípios regentes da licitação}

Inicialmente há de salientar-se que o procedimento licitatório, necessariamente, deverá observar aos princípios básicos da Administração, tanto os firmados no artigo 37, "caput" da Constituição, como também os decorrentes da própria Carta, eis que abrangem a todas as ações da Administração Pública tanto Direta como Indireta.

Além dos aspectos positivados como características básicas no Estatuto das Licitações, o artigo $3^{\circ}$ amplia o espectro de princípios a serem observados no

2 Direito Administrativo, página 299. 
procedimento de seleção de melhor proposta para atender ao contrato de interesse da Administração, dentre os quais:

\section{1 - Princípio da Isonomia}

Princípio essencial e norteador de todo o procedimento administrativo que encontra-se previsto no "caput" do artigo $5^{\circ}$, como também no artigo 37 , XXI, ambos da $\mathrm{CF}$.

Diversamente da interpretação ofertada pelo Direito Privado, onde todos são iguais, no campo do Direito Público, que rege a atuação da Administração Pública, deve ser interpretado como o dever imposto à Administração, em tratar a todos com igualdade, sem favorecimentos ou cláusulas facciosas.

Tal construção decorre da idéia da supremacia do interesse público sobre o interesse privado, e que tais interesses são materializados através da atuação da Administração Pública que acaba recebendo um tratamento diferenciado pelo Direito, para assegurar o pleno atendimento ao interesse público.

Visando acentuar a necessidade de oferecer tratamento isonômico aos interessados no futuro contrato com a Administração, o artigo $3^{\circ}$, parágrafo primeiro, em seus incisos I e II da Lei de Licitações, expressamente veda condutas discriminatórias assim como no parágrafo segundo, reafirma a idéia de igualdade.

Objetivamente visa impedir discriminação gratuita através de imposição de cláusulas e de julgamento faccioso sendo que sua infração constitui-se em desvio de poder.

Não se traduz em idéia absoluta, e sim em conceito que nos remete a Rui Barbosa, onde "é a igualdade entre os iguais", ou seja, os que preencham as mesma condições.

Assim, é possível verificar não constituir infração à isonomia e, portanto, não materializa discriminação odiosa a exigência de qualificação prévia dos futuros contratados, pois esta, a qualificação, objetiva oferecer segurança à Administração, garantindo a efetiva entrega, realização do serviço ou da obra pelo contratado, preservando o interesse público, objetivo maior da Administração.

O próprio artigo $37, \mathrm{XXI}$, da CF que estabelece a obrigatoriedade ao Poder Público de licitar quando contrata, autoriza o estabelecimento de requisitos de qualificação técnica e econômica, desde que indispensáveis ao cumprimento das obrigações, não se constituindo, assim, em infração ao princípio da isonomia.

\section{2 - Procedimento Formal}

Assegurada sua observância no artigo $4^{\circ}$, parágrafo único, do Estatuto de Licitações, visa basicamente a vinculação da Administração a prescrições legais, reafirma a submissão da Administração ao princípio da legalidade inscrito no artigo 37, "caput" da CF. Também acaba por reafirmar a incidência do princípio da vinculação ao edital, tratado no item 3.5.

Ressalte-se não constituir mero formalismo, ou seja, apenas culto à forma, pois o reconhecimento de nulidades, dar-se-á apenas nas hipóteses em que comprovada- 
mente haja danos para as partes, principalmente nas situações que porventura frustrem o caráter competitivo do certame.

A formalidade tem sua incidência no sentido de assegurar a igualdade, a moralidade, a probidade, a impessoalidade, entre outros aspectos a serem preservados e atendidos pela Administração; porém, como ressaltado, somente ensejará a anulação, tanto na esfera administrativa como judicial, na hipótese de prejuízo às partes. Caso contrário, ante a necessidade de celeridade das ações administrativas para atender ao interesse público, e em atendimento ao princípio da economia processual e da segurança jurídica, permanece o procedimento produzindo seus regulares efeitos.

\section{3 - Publicidade}

Trata-se de princípio positivado no artigo 37, "caput" da CF/88, que ante a natureza da Administração Pública em gerir os interesses da sociedade, constitui-se em condição de eficácia de todas as ações administrativas, exceto aquelas que, por sua relevância, são declaradas por lei como sigilosas, citando-se, por exemplo, as questões que envolvam segurança nacional.

Nesta linha, todos os atos realizados no processo de seleção da melhor proposta para a Administração são públicos, a partir do que dispõe expressamente o artigo $4^{\circ}$, "caput" e o artigo $3^{\circ}$, parágrafo terceiro, ambos da Lei $n^{\circ} 8.666 / 93$ e suas alterações posteriores.

Nas licitações, abrange desde o aviso resumido, que informa aos possíveis interessados em participar do processo, até seu resultado final. Cabe, porém, ressaltar, que o julgamento poderá ser reservado, impondo-se à Administração, ou seja, àqueles encarregados de promover o julgamento, declarar expressamente a decisão e seus motivos ensejadores, dando a estes a necessária publicidade. Impõe, ainda, salientar que julgamento é amplamente diferente de abertura de propostas na licitação, eis que é da própria essência deste ato sua realização pública.

Das seis modalidades de licitação hoje existentes, apenas a carta-convite não se inicia por publicação no Diário Oficial tanto estadual como no órgão de divulgação oficial dos atos do Município, e ainda, em jornal de grande circulação, conforme disposto no artigo 21, incisos II e III, do Estatuto das Licitações.

Destes incisos indicados surgem duas questões:

a - nos termos dos artigos 18 e 30 , ambos da CF, que asseguram autonomia aos Municípios, seria constitucional a iniciativa do legislador federal ordinário, em determinar publicações de licitações realizadas por aqueles, no Diário Oficial do respectivo Estado, eis que dispõem de órgão oficial de divulgação de seus atos?

$\mathrm{b}$ - como define-se "jornal de grande circulação no Estado, no Município ou na região"?

Cuidando destas indagações, em decisão monocrática do Conselheiro Fulvio Julião Biazzi, o Tribunal de Contas do Estado de São Paulo, no processo TC $N^{\circ}$ 6736/026/00, assim estabeleceu:

I- “À vista do que dispõe a lei, a Municipalidade está obrigada a publicar seus resumos de editais de Concorrência, Tomada de Preços, Concursos e 
Leilōes no Diário Oficial do Estado (independentemente de possuir ou não imprensa oficial própria), em jornal de grande circulação no Estado, e, ainda, se existir, em jornal de grande circulação no Municipio ou Região".

2 - "O conceito de jornal de grande circulação está afeto à tiragem mínima diária de periódico em 20.000 exemplares, atestada por certidão emitida pelo Sindicato das Empresas Proprietárias de Jornais e Revistas no Estado de São Paulo". ${ }^{3}$

\section{4 - Sigilo na Apresentação das Propostas}

Trata-se de princípio que decorre da necessária igualdade a ser dispensada pela Administração aos participantes e encontra-se positivada no Estatuto das Licitações nos artigos $3^{\circ}$, parágrafo primeiro, e 43 , parágrafo primeiro.

Tão relevante que sua inobservância, "in casu" a abertura antecipada, enseja anulação e ainda sujeita o infrator às penalidades do artigo 94, ou seja, "detençăo de dois a três anos e multa".

\section{5 - Vinculação ao Edital}

O instrumento convocatório é de extrema importância, a partir do próprio tratamento legislativo nos termos do artigo $3^{\circ}$, "caput", que vincula a Administração ao mesmo, como também no artigo 41, "caput", onde tal conceito é reiterado. Ressalte-se, também, ser decorrente da necessidade de oferta de tratamento isonômico, por parte da Administraçạa, a todos os interessados.

Extremamente relevante que a doutrina é uníssona em declará-lo como princípio básico, denominando o edital como "lei interna da licitação", que vincula as partes e a Administração.

Cabe ressaltar que a elaboração do edital tem natureza discricionária, porém, após iniciado o procedimento com sua publicação, quaisquer alterações impõem a obrigatoriedade de reabertura do prazo para apresentação de propostas pelos interessados, nos termos do artigo 21 da Lei $\mathrm{n}^{\circ} 8.666 / 93$.

Não obstante o caráter discricionário mencionado, o artigo 40 da Lei de Licitações impõe os requisitos indispensáveis à elaboração do instrumento inaugural do certame, com o inciso I estabelecendo que integrará o referido instrumento, o objeto da licitação, em descrição clara e sucinta.

Esta descrição minuciosa e adequada impõe-se ante a necessidade de a Administração estabelecer com clareza o objeto que necessita para o futuro ajuste, e que permita aos interessados a oferta de propostas, em bases que assegurem a igualdade.

Relevante ressaltar a descrição do objeto pretendido pela Administração, que sendo realizada genericamente, constitui-se em falha que a Administração só percebe

3 DOE -04.07 .00$. 
no momento em que recebe as propostas, ou quando recebe o produto. Exemplo típico: aquisição de sabão em pó para limpeza, via de regra, extremamente arenoso.

A Administração, na escolha do objeto a ser licitado, goza de discricionariedade, eis que a ela compete avaliar e estabelecer o que efetivamente necessita para atender ao interesse público, porém, deverá fazê-lo com a necessária descrição de características imprescindíveis para o atendimento do objeto pretendido pela Administração.

Ressalte-se que tal descrição, minuciosa de características, não venha a obstar a competitividade e, por conseguinte, constituir-se em flagrante infração ao princípio da impessoalidade, regente das ações administrativas.

CPTM - Licitação de veículos com motoristas e despachantes de tráfego para prestação de serviços em áreas atendidas pelo Trem Metropolitano. Busca de eficiência no desenvolvimento do serviço público, comprometida pela ancianidade da frota. Solução razoável e não adversa à economicidade. adotada em sede de juízo de discricionário da Administração - Regularidade. (TC 1108/026/98- TCESP - Relator Conselheiro Cláudio Ferraz Alvarenga) ${ }^{4}$

MANDADO DE SEGURANCA - TOMADA DE PREÇOS - LICITA$C \tilde{A} \boldsymbol{O}$ - Ao especificar os itens que pretende adquirir a Administração tem a liberdade de escolher os mais adequados às suas necessidades. STJ Recurso em MS n' 1207-0-PR - Relator Ministro José de Jesus Filho) ${ }^{5}$

Neste sentido, é de observar-se a decisão proferida pelo Superior Tribunal de Justiça:

Administrativo. Licitação. Habilitação. Mandado de Segurança. Edital. 1. As regras do edital de procedimento licitatório devem ser interpretadas de modo que, sem causar prejuízo à Administração e aos interessados no certame, possibilitem a participação do maior número de possível de concorrentes, a fim de que seja possibilitado se encontrar, entre várias propostas a mais vantajosa. 2. 'Não há de se prestigiar posição decisória assumida pela Comissão de Licitação que inabilita concorrente com base em circunstância impertinente ou irrelevante para o específico objeto do contrato, fazendo exigência sem conteúdo de repercussão para a configuração da habilitação jurídica, da qualificação técnica, da qualificação econômicofinanceira e regularidade fiscal'. 3. Se o edital exige que a prova da habilitação jurídica da empresa deve ser feita, apenas, com a apresentação do "ato constitutivo e suas alterações, devidamente registradas ou arquivadas na repartição competente, constando dentre seu objetivos a exclusão de serviços de Radiodifusão..., é excessiva e sem fundamento legal a inabi- 
litação de concorrentes sob a simples afirmação de que cláusulas do contrato social não se harmonizam com o valor total do capital social e com o correspondente balanço de abertura, por tal entendimento se vago $e$ impreciso. 4. Segurança Concedida. (STJ - MS 5606/DF - Rel. Min. José Delgado $)^{6}($ g. n)

\section{6 - Julgamento Objetivo}

Importante observar que tal princípio também decorre do princípio da igualdade e encontra-se estabelecido nos artigos 44 e 45 da Lei de Licitações.

O critério deve necessariamente ser eleito no edital, ou seja, previamente à apresentação de propostas, devendo ser escolhido dentre as formas elencadas no artigo 46 da Lei de Licitações, ou seja, menor preço, melhor técnica, técnica e preço e maior oferta, aspectos eminentemente objetivos.

Observa-se, assim, a reafirmação da relevância para o procedimento licitatório do princípio da vinculação ao edital, tratado no item 3.5.

Ante tais imposições fica afastada toda e qualquer possibilidade de discricionariedade no ato do julgamento de escolha da melhor proposta, restando à Administração atuar vinculadamente ao critério eleito no edital, impedindo toda e qualquer possibilidade de atuação movida por subjetivismo.

\section{4 - Habilitação prevista no artigo $27, \mathrm{I}$ a $\mathrm{VI}$}

Ao tratar no item 3.1 do princípio da isonomia, ficou jacente a idéia de que a igualdade não é uma relação absoluta, e sim admite uma certa relativização no sentido de estabelecer um tratamento isonômico entre iguais, ou seja, aqueles que encontram-se nas mesmas condições.

Impõe rememorar que o próprio texto constitucional no artigo 37, XXI, da CF, ao tratar da obrigatoriedade da Administração licitar para obtenção de contratos de seu interesse, admite a inserção no instrumento convocatório de cláusulas que estabeleçam condições mínimas, econômicas e técnicas, entre os possíveis participantes.

Neste sentido, o legislador ordinário veio a inserir no Estatuto das Licitações, seção específica tratando de estabelecer regras claras e objetivas no momento de assegurar tratamento isonômico entre os possíveis interessados, e ainda, no sentido de evitar abusos discriminatórios por parte da Administração.

\section{SEÇÃO II}

Da Habilitação

Art. 27. Para a habilitação nas licitações exigir-se-á dos interessados, exclusivamente, documentação relativa a:

I- habilitação jurídica;

6 DJ de 13.05.98. 
II - qualificação técnica;

III - qualificação econômico-financeira;

IV - regularidade fiscal;

$V$ - cumprimento do disposto no inciso XXXIII do art. $7^{\circ}$ da Constituição

Federal." (Redação da lei no 9.854, de 27 de outubro de 1999)

Impõe, neste momento, verificar-se uma situação bastante interessante que vem ocorrendo nas licitações dos diversos entes e entidades da Administração Pública brasileira, no que tange à juntada de documentos comprobatórios nesta fase de habilitação dos interessados.

Trata-se da forma de exibição dos documentos, que, vez por outra, exige-se apenas seu original, sendo negada, no edital, a possibilidade de cópia reprográfica, e até mesmo quando admitida esta, Ihe é exigida a autenticação.

No que tange à exigência de apresentação de cópias autênticas, há suficiente tratamento legislativo no artigo 32 "caput" da Lei de Licitações, que expressamente dispõe:

Art. 32 - Os documentos necessários à habilitação poderão ser apresentados em original, 'por qualquer processo de cópia autenticada por cartório competente ou por servidor da administraçāo' ou publicação em órgão da imprensa oficial (Redação dada pela Lei $n^{\circ} 8.883$ de 8.6.1.994) (g.n.)

Em pleno agasalho a esta expressa disposição legal, já decidiu o Tribunal de Contas do Estado de São Paulo, ao apreciar impugnação a edital levada a seu plenário que, ao final veio a determinar a necessária adequação ao quanto dispõe a Lei de Licitações, conforme observa-se:

"Habilitação. Documentos, proibida a exibição de cópia autenticada. Des. respeito à regra do artigo 32" caput da Lei $8.666 / 93$ (Processo $\mathrm{n}^{\circ}$ 29345/026/01 - Exame Prévio de Edital. Rel. Cons. Robson Marinho TCESP) ${ }^{7}$

Outra situação que merece ser salientada, é a de que até recentemente havia importante desacerto entre provimento da Corregedoria Geral de Justiça, do Tribunal de Justiça do Estado de São Paulo, ao fazer editar Normas de Serviços, editou o Provimento $n^{\circ} 50.1989$ estabelecendo que nas certidões dos Distribuidores deverá constar a seguinte observação : "Esta certidão só tem validade no original".

Constatado o conflito entre a Norma de Serviço com o disposto no artigo 32 "cuput" da Lei de Licitações, tal redação veio sofrer modificação em novembro de 2.002, através do Provimento 21/2.002 acrescendo-se ao final: "ressalvado o teor do artigo 32 da Lei $n^{\circ} 8.666 / 93$." 


\section{1 - Habilitação Jurídica}

Visa assegurar que o contratado esteja apto a assumir os compromissos decorrentes de sua seleção através do processo licitatório, verificando a existência de rol exaustivo de documentos, para demonstração de capacidade jurídica do interessado, no artigo 28 da Lei 8.666/93 com suas alterações posteriores, como se observa:

Art. 28. A documentação relativa à habilitação jurídica, conforme o caso, consistirá em:

I - cédula de identidade;

II - registro conercial, no caso de empresa individual;

III - ato constitutivo, estatuto ou contrato social em vigor, devidamente registrado, em se tratando de sociedades comerciais, e, no caso de sociedades por ações, acompanhado de documentos de eleição de seus administradores;

IV - inscriçāo do ato constitutivo, no caso de sociedades civis, acompanhada de prova de diretoria em exercício;

$V$ - decreto de autorização, em se tratando de empresa ou sociedade estrangeira em funcionamento no País, e ato de registro ou autorização para funcionamento expedido pelo órgão competente, quando a atividade assim o exigir.

Apesar de aparentemente simples e razoáveis as exigências, vez por outra, assiste-se a uma série de representações perante os Tribunais de Contas dos Estados ou mesmo do Judiciário, visando dirimir dúvidas, ou mesmo elidir conflitos quanto a exigências relativas a estes aspectos.

Apesar de explicitado no artigo 28 , inciso $\mathrm{V}$, parte final do dispositivo reproduzido, vez por outra acaba-se constatando a inserção de exigência de registro em órgãos próprios.

Tal exigência assume caráter de licitude, somente quando a atividade assim o exigir como entidades bancárias, securitárias, sociedades de advogados (Lei 8.904/94), de engenheiros (Lei 5.194/96), entre outros.

Neste sentido é de observar-se a manifestação do Tribunal de Contas Paulista, ao abordar a questão:

DOCUMENTAÇÃO E REGISTRO CADASTRAL - Excluídos como fundamento de decisão as exigências relativas à qualificação econômico-financeira (item 6.I.2, letras, $B, b .1, b .2$ e b.3 e d) salvo, quanto a esta, a obrigação do registro sindical, 'só é admissível nos caso em que o exercício de atividade profissional esteja condicionada, por lei, à inscrição na entidade de classe competente'. Inadmissibilidade, inteligência dos artigos 30 e 31 da Lei federal $n^{\circ} 8.666 / 93$, Recurso Desprovido.

(Processo TC - 214/003/98 / Rel. Cons. Edgard Camargo Rodrigues TCESP $)^{8}$ 
Em relação a este mesmo dispositivo da Lei 8.666/93, também em algumas situações, tem-se observado conflito entre as exigências de habilitação jurídica realizadas pela Administração e os interessados em participar dos certames. Trata-se da forma de apresentação das empresas e sociedades, que muitas vezes, nos termos de expressos dispositivos legais, revestem-se de formas que dispensam determinados registros, como por exemplo, na Junta Comercial.

A título exemplificativo, cabe observar a decisão do Tribunal de Justiça de São Paulo, tratando de empresas jornalísticas, que mediante expressa disposição legal, artigo $3^{\circ}$ da Lei $n^{\circ} 5.250 / 67$, podem ser constituídas sob a forma de sociedade civil, dispensado assim, o registro perante a Junta Comercial do Estado de São Paulo.

MANDADO DE SEGURANÇA - LICITAÇÃO - EMPRESA JORNALÍSTICA - REGISTRO NA JUNTA COMERCIAL - Podendo a empresa jornalística revestir-se da forma de sociedade civil (art. $3^{\circ}$ da Lei $n^{\circ}$ 5.250/67) a cláusula constante de licitação que exige a prova do registro da empresa na Junta Comercial é discriminatória, mesmo porque a Lei de Licitações permite no artigo $28, I V$, a habilitação jurídica de sociedade civil interessada no certame mediante a exibição de inscrição de seus atos constitutivos e prova de diretoria em exercício. Recurso que se dá provimento, para conceder-se a segurança, a fim de que o certame seja julgado pelo critério de menor preço. (Ap. 243.003-1, Relator Dês. Lineo Peinado) ${ }^{9}$

\section{2 - Qualificação técnica}

Tal possibilidade de exigência deferida à Administração, visa apenas assegurar que esta venha a contratar empresas ou entidades que possam desincumbir-se adequadamente do objeto do contrato, que tem por finalidade básica e indisponível, atender ao interesse público.

Neste sentido, tanto o constituinte originário como o legislador ordinário, em seus respectivos misteres, fizeram inserir autorização à Administração, exigir demonstração de experiência anterior naquela atividade a ser desincumbida mediante a assinatura do contrato.

Art. 30. A documentação relativa à qualificação técnica limitar-se-á a:

I - registro ou inscrição na entidade profissional competente;

$I I$ - comprovação de aptidão para desempenho de atividade pertinente $e$ compatível em características, quantidades e prazos com o objeto da licitação, e indicação das instalações e do aparelhamento e do pessoal técnico adequados e disponiveis para a realização do objeto da licitação, bem como da qualificą̧āo de cada um dos membros da equipe técnica que se responsabilizará pelos trabalhos; 
III - comprovação, fornecida pelo órgão licitante, de que recebeu os documentos, e, quando exigido, de que tomou conhecimento de todas as informaçōes e das condiçōes locais para o cumprimento das obrigaçōes objeto da licitação;

IV - prova de atendimento de requisitos previstos em lei especial, quando for o caso

$\S 1^{\circ} \mathrm{A}$ comprovação de aptidão referida no inciso Il do caput deste artigo, no caso das licitações pertinentes a obras e serviços, será feita por atestados fornecidos por pessoas jurídicas de direito público ou privado, devidamente registrados nas entidades profissionais competentes, limitadas as exigências a:

I- capacitação técnico-profissional: comprovação do licitante de possuir em seu quadro permanente, na data prevista para entrega da proposta, profissional de nivel superior ou outro devidamente reconhecido pela entidade competente, detentor de atestado de responsabilidade técnica por execução de obra ou serviço de características semelhantes, limitadas estas exclusivamente às parcelas de maior relevância e valor significativo do objeto da licitação, vedadas as exigências de quantidades minimas ou prazo máximos;

II - (Vetado);

a) (Vetado);

b) (Vetado);

$\S 2^{\circ}$ As parcelas de maior relevância técnica e de valor significativo, mencionadas no parágrafo anterior, serão definidas no instrumento convocatório.

$\S 3^{\circ}$ Será sempre admitida a comprovação de aptidāo através de certidōes ou atestados de obras ou serviços similares de complexidade tecnológica $e$ operacional equivalente ou superior.

$\S 4^{\circ}$ Nas licitações para fornecimento de bens, a comprovação de aptidão, quando for o caso, será feita através de atestados fornecidos por pessoa jurídica de direito público ou privado.

$\$ 5^{\circ}$ É vedada a exigência de comprovação de atividade ou de aptidão com limitações de tempo ou de época ou ainda em locais específicos, ou quaisquer outras não previstas nesta lei, que inibam a participação na licitação. $\S 6^{\circ}$ As exigências minimas relativas a instalaçōes de canteiros, máquinas, equipamentos e pessoal técnico especializado, considerados essenciais para o cumprimento do objeto da licitação, serão atendidas mediante a apresentação de relação explícita e da declaração formal da sua disponibilidade. sob as penas cabiveis, vedada as exigências de propriedade e de localização prévia.

$\S 7^{\circ}$ (Vetado).

I- (Vetado);

II - (Vetado).

$\S 8^{\circ}$ No caso de obras, serviços e compras de grande vulto, de alta complexidade técnica, poderá a administração exigir dos licitantes a metodologia 
de execução, cuja avaliação, para efeito de sua aceitação ou não, antecederá sempre à análise dos preços e será efetuada exclusivamente por critérios objetivos.

$\S 9^{\circ}$ Entende-se por licitą̧ão de alta complexidade técnica aquela que envolva alta especialização, como fator de extrema relevância para garantir a execução do objeto a ser contratado, ou que possa comprometer a continuidade da prestação de serviços públicos essenciais.

$\S 10$. Os profissionais indicados pelo licitante para fins de comprovação da capacitação técnico-operacional de que trata o inciso I do $\$ I^{\circ}$ deste artigo deverão participar da obra ou serviço objeto da licitação, admitindo-se a substituição por profissionais de experiência equivalente ou superior, desde que aprovada pela administração.

$\$ 11$. (Vetado).

$\S 12$. (Vetado).

A demonstração desta aptidão técnica, dá-se através da apresentação de atestados emitidos por entidades ou empresas privadas, ou mesmo por entes de direito público interno devidamente registrados em órgãos profissionais, nos termos do que dispõe o artigo art. $30 \S 1^{\circ}$, I, da Lei de Licitações.

LICITAÇÃO - CAPACIDADE TÉCNICA - Apresentação de capacidade operacional em número inferior ao exigido no edital. Quantitativos e prazos. Proporcionalidade com o objeto da licitação. Segurança Denegada. Recurso Improvido. Ap. Cível 57.513-5/1 - Relator Dês. Alves Beviláqua Tribunal de Justiça de São Paulo. ${ }^{10}$

EXAME PRÉVIO DE EDITAL - Serviços de Infra-estrutura viária urbana (galeria de águas pluviais, guias, sarjetas e pavimentação asfáltica), com fornecimento de materiais equipamentos e mão-de-obra a serem realizados, em quantidades certas e por preços unitários previamente orçados, em vias e logradouros públicos identificados - Execução por contratado único, em regime de empreitado por preço global, com pagamentos periódicos pela contratante - Escolha discricionária pela Administração. 'Comprovação de capacidade técnico-operacional do licitante, pela evidência da anterior execução, em determinados prazos, de certos quantitativos e pertinentes à parcela de maior relevância do objeto licitado, de antemão definidas no edital - Regularidade'. (Processo TC 24336/026/01. - Rel. Cons. Cláudio Ferraz Alvarenga - TCESP $)(\text { g. n. })^{11}$

No edital de licitação, permite-se apenas exigência de quantitativos pertinentes e compatíveis com o objeto. Recurso Desprovido (Processo TC 1539/026/96 - Rel. Cons. Cláudio Ferraz Alvarenga - TCESP) ${ }^{12}$

10 DJ de 02.03.1999.

11 DOE de 04.10.2001.

12 DOE de 02.08.2000. 
1. HABILITAÇÃO TÉCNICA reconhecida pela via 'de critérios objetivos não pode ser destruida por afirmações de índole subjetiva', contrapondo-se às avaliações vinculadas as disposições editalícias. A legislação de regência louva os critérios objetivos e da vinculação ao instrumento convocatório. (\$ $1^{\circ}$, art. 44, Lei $n^{\circ}$ 8.666/93; art. 14 Lei $n^{\circ}$ 8.987/95) (STJ, MS 5389/DF - Rel. Min. Milton Pereira) ${ }^{13}$

Não obstante o expresso mandamento contido no artigo $30, \S 6^{\circ}$ da Lei de Licitações, vedando expressamente a exigência de propriedade de bens ou mesmo de equipamentos, no cotidiano das relações da Administração Pública com os particulares interessados em futuros contratos, tem-se assistido conflitos com a exigência por parte do Poder Público de demonstração de propriedade de bens e equipamentos a serem utilizados no futuro ajuste.

CONTRATO - A pré-condição de propriedade ou opção de compra de um terreno para a consecução do objeto, constitui 'restrição ao caráter competitivo do certame'. Recurso conhecido. Improvido. V. U. (Processo TC - 28552/026/96 - Rel. Cons. Eduardo Bittẹncourt Carvalho TCESP) $(\text { g. } n)^{14}$

RESTRICÃ̃O À COMPETITIVIDADE - Exigência de Fornecimento de terreno ou opção de compra - Condição limitadora da competitividade - Recurso Improvido. (Processo TC 1234/026/97 - Renato Martins Costa - TCESP) $(\text { g.n. })^{15}$

LICITAÇÃO. Edital - Cláusulas sob suspeita de ilegalidade. Exame prévio. Exigência na fase de habilitação), de comprovação: 1) de propriedade ou posse de área de 5.000 metros quadrados no perímetro urbano, com cobertura, para a guarda de veículos guinchados; 2) de apresentação de croquis de localização do imóvel; 3) de propriedade de guinchos e equipamentos; e 4) de apresentação de laudo de vistoria dos guinchos retro apontados e de veículos anteriormente apreendidos pela licitante. 'Exigências restritivas. Correçōes determinadas'. (Processo TC-2492/026/01 Rel. Cons. Robson Marinho - TCESP) (g. n. $)^{16}$

Aparentemente esta situação é de solução pacífica ante expresso dispositivo legal e manifestações tanto de Tribunais de Contas como de órgãos jurisdicionais, porém, tem-se observado que em situações excepcionalíssimas, tendo por base a natureza da atividade e dos serviços a serem prestados, têm sido admitidas exigências de propriedade de bens, equipamentos e equipe já constituída.

13 DJ de 21.09.1988.

14 DOE de 26.10.2001.

15 DOE de 24.08.2002.

16 DOE de 28.09.2001 
Em esclarecedora decisão proferida pelo Tribunal de Justiça do Estado de São Paulo, cuja reprodução parcial faz-se a seguir, é possível observar que há hipóteses onde o interesse público prepondera, recebendo um tratamento diferenciado, autorizando exigências de propriedade e demonstração de possibilidade de assunção imediata da atividade pelo contratado.

As exigências motivadoras da inabilitação da recorrente, não são ilegais e nem abusivas. A administração tem o dever de se assegurar da capacidade operacional das pessoas que juridicas candidatas a contratar, podendo estipular exigências que visem comprovar essas condições, o que se situa dentro da margem de discricionariedade deferida ao agente do Poder Público. Como bem afirmado, na decisão recorrida "a atividade licitada é perigosa, significa colocar na rua pessoas armadas, que por isso demandam treinamento específico (além de treinamento técnico na atividade: técnicas de defesa, de direção, de controle de pessoas etc.), o que demanda tempo $e$ investimento". Em que pese a insistência da recorrente ao interpretar os dispositivos legais elencados, no sentido de ser inválida a exigência de três atestados de capacidade técnica, fornecidas por pessoas jurídicas de direito público ou privado, 'comprovando a aptidão para o desempenho de atividade pertinente e compativel em características com o objeto da licitação, declaração do número de armas registradas, número de vigilantes bancá. rios, com vínculo empregatício, tais exigências não restringem e nem comprometem o caráter competitivo do certame e näo ferem o princípio da isonomia garantido pela Constituição Federal'. Bem precisas a respeito da questão, as palavras da douta Procuradora de Justiça, Dra. Maria do Carmo Ponchon da Silva Purcini, "no tocante à apresentação de três atestados, a exigência se justifica, na medida em que dispõe de um para cada núcleo do contrato. Assim, dada a natureza segmentada do serviço a ser contratado, impõe-se a apresentação de atestados específicos de cada núcleo, não se mostrando portanto, abusiva a exigência, em número de três. 'De outro lado, ainda, a declaração do número de armas, devidamente registrada, e do número de vigilantes bancários com vínculo empregatício, tratam-se de exigências que vão garantir a execução do contrato. Obviamente que os serviços devem ser prestados tão logo adjudicada e homologada a licitação, não podendo o impetrado ficar aguardando a compra $e$ registro de armas, a contratação de pessoal, vigilante bancário e o seu respectivo treinamento. São providências que demandam tempo, afora os entraves burocráticos. Por isso que o impetrado exige dos licitantes uma estrutura pronta e capaz de assumir a execução do contrato'. (Apelação $n^{\circ}$ 90,930-5/6 - Rel. Dês.. Scarance Fernandes - Tribunal de Justiça do Estado de São Paulo) (g. n. $)^{17}$ 


\section{3 - Qualificação econômico-financeira}

Justifica-se tal possibilidade no mesmo fundamento relativo aos demais aspectos, ou seja, na possibilidade de a Administração assegurar-se de que o contratado desincumbir-se-á adequadamente em relação ao objeto do contrato, visando preservar o interesse público, finalidade básica dos contratos administrativos.

Os documentos exigiveis para demonstração da boa saúde financeira do interessado no futuro ajuste com o Poder Público, encontram-se elencados no artigo 31 da Lei de Licitações, a seguir reproduzido:

Art. 31. A documentaçâo relativa à qualificação econômico-financeira limitar-se-á a:

$I$ - balanço patrimonial e demonstrações contábeis do último exercício social, já exigiveis e apresentados na forma da lei, que comprovem a boa situação financeira da empresa, vedada a sua substituição por balancetes ou balanços provisórios, podendo ser atualizados por índices oficiais quando encerrados a muis de 3 (três) meses da data de apresentação da proposta; II - certldão negativa de falencia ou concordata expedida pelo distribuidor da sede da pessoa juridica, ou de execução patrimonial, expedida no domicílio da pessoa fisica;

III - garantia, nas mesmas modalidades e critérios previstos no caput e $\S$ $1^{\circ}$ do art. 56 desta lei, limitada a $1 \%$ (um por cento) do valor estimado do objeto da contratação.

$\$ 1^{\circ}$ A exigencia de indices limitar-se-á à demonstração da capacidade financeira do licitante com vistas aos compromissos que terá que assumir caso the seja adjudicado o contrato, vedada a exigência de valores mínimos de faturamento anterior, indices de rentabilidade ou lucratividade.

$\S 2^{\circ}$ Administração, nas compras para entrega futura e na execução de obras e serviços, poderá estabelecer, no instrumento convocatório da licitação, a exigência de capital mínimo ou de patrimônio líquido mínimo, ou ainda as garantias previstas no $\$ 1^{\circ}$ do art. 56 desta lei, como dado objetivo de comprovação da qualificação econômico-financeira dos licitantes e para efeito de garantia ao adimplemento do contrato a ser ulteriormente celebrado.

$\$ 3^{\circ} O$ capital mínimo ou o valor do patrimônio líquido a que se refere o parágrafo anterior, não poderá exceder a $10 \%$ (dez por cento) do valor estimado da contratação, devendo a comprovação ser feita relativamente à data da apresentação da proposta, na forma da lei, admitida a atualização para esta data através de índices oficiais.

$\$ 4^{\circ}$ Poderá ser exigida, ainda, a relação dos compromissos assumidos pelo licitante que importem diminuição da capacidade operativa ou absorção de disponibilidade financeira, calculada esta em função do patrimônio líquido atualizado e sua capacidade de rotação.

$\S 5^{\circ}$ A comprovação da boa situação financeira da empresa será feita de 
forma objetiva, através do cálculo de indices contábeis previstos no edital e devidamente justificados no processo administrativo da licitação que tenha dado início ao certame licitatório, vedada a exigência de índices e valores não usualmente adotados para a correta avaliação de situação financeira suficiente ao cumprimento das obrigações decorrentes da licitação. $\S 6^{\circ}$ (Vetado).

A partir da redação do " caput" do dispositivo reproduzido, constata-se que 0 rol de exigências no sentido de qualificação econômico financeira é exaustivo, ou seja, não poderá sofrer acréscimo de quaisquer outros.

Não obstante tal característica, tem-se observado comumente a inserção em editais de procedimentos licitatórios, exigência de exibição de Certidão Negativa de Protestos para fins de habilitação econômico-financeira.

Instado a manifestar-se, a Corte Paulista de Contas vem reiteradamente manifestando-se no sentido de que sejam promovidas alterações nos editais, afastando tal exigência por ilegal, conforme se observa nos dois julgados a seguir:

TC de São Paulo - recomendando a impossibilidade de exigir documentos além dos estabelecidos em lei. ..... " 'recomendando à Prefeitura' Municipal de Americana que, nas próximas licitações, 'deixe de exigir dos licitantes' inscrição no P.A.T. 'e certidão negativa de protestos'” (Processo TC 1884/003/00 - Rel. Cons. Subst. José Laury Miskulin - TCESP) (g.n. $)^{18}$

"A exigência contida no subitem 5.1.3.d, do edital relativa a 'apresentação de Certidão Negativa de Protesto, extrapola os limites do artigo 31, II do Estatuto das Licitações devendo ser suprimida do ato convocatório..."” (Processo TC - 26483/026/01 e TC - 27130/026/01 - Rel. Cons. Fulvio Julião Biazzi - TCESP) $(\text { g. n. })^{19}$

\section{4 - Regularidade fiscal}

Com a mesma característica de rol exaustivo, estabeleceu o legislador infraconstitucional, os documentos possíveis de serem exigidos no procedimento de habilitação nas licitações.

Art. 29. A documentação relativa à regularidade fiscal, conforme o caso, consistirá em:

$I$ - prova de inscrição no Cadastro de Pessoas Físicas (CPF) ou no Cadastro Geral de Contribuintes (CGC);

II - prova de inscrição no cadastro de contribuintes estadual ou municipal, se houver, relativo ao domicílio ou sede do licitante, pertinente ao seu ramo de atividade e compativel com o objeto contratual; 
III - prova de regularidade para a Fazenda Federal, Estadual e Municipal do domicílio ou sede do licitante, ou outra equivalente, na forma da lei; IV - prova de regularidade relativa à Seguridade Social e ao Fundo de Garantia por Tempo de Serviço (FGTS), demonstrando situação regular no cumprimento dos encargos sociais instituidos por lei.

A apuração de regularidade fiscal vem ensejando alguma divergência entre Administração e participantes, no que tange a interpretação oferecida pelos entes ou entidades estatais ao exigirem como condição a ser preenchida pelos interessados: prova de quitação dos tributos e, imposição de comprovação obrigatória de regularidade com as Fazendas Federal, Estadual e Municipal, independentemente da situação.

No tocante à prova de quitação de tributos, há de se observar que, "regularidade com o Fisco não significa ausência de débito", como, por exemplo, no caso de parcelamento de tributos vencidos, ou em situações em que se está discutindo judicialmente a validade de determinada exigência, com a sua suspensão liminar.

Assim, o próprio CTN contempla a expedição de certidões positivas de débitos, com efeito de negativa:

Artigo 206 - Tem os mesmo efeitos previstos no artigo anterior a certidão que conste a existência de créditos não vencidos, em curso de cobrança executiva em que tenha sido efetivada a penhora, ou cuja exigibilidade esteja suspensa.

Neste sentido observe-se a decisão do TC de São Paulo que suspendeu licitação em Mauá, indicando que:

"o edital ao tratar da habilitação dos licitantes, 'exigiu prova de quitação com a Fazenda Federal, Estadual e Municipal através de certidão negativa dentro do prazo de validade em vigor'. A exigência estaria descompassada com a Lei $n^{\circ} 8.666 / 93$, cujo artigo 29, II, apenas se refere a regularidade, certo que a doutrina considera ilegal o edital que exija prova de quitação. (Processo TC - 2339/026/02 - Rel. Cons. Cláudio Ferraz de Alvarenga $-T C E S P)^{20}$

O outro aspecto salientado quanto a regularidade fiscal, refere-se a exigência de demonstração de inscrição perante as Fazendas Estadual ou Municipal, estabelecida no artigo 29, II, do Estatuto das Licitações já reproduzido, que as Administrações vêm exigindo como obrigatórias em todas as situações, inobservando que, entre vírgulas, encontra-se a expressão $S E H O U V E R$, ou seja, somente exigir-se-á comprovação se a atividade do interessado impuser-lhe a condição de contribuinte para esta ou aquela Fazenda. 
Nesta linha devidamente provocado, o Superior Tribunal de Justiça já decidiu:

COMPROVAÇÃO DE INSCRIÇÃO NO CADASTRO DE CONTRIBUINTES DA FAZENDA ESTADUAL E OU MUNICIPAL - artigo 29, II, da LL A entremeação, na redação da cláusula, da expressão - se for o casoocasiona confusão, dubiedade na interpretação desse item, tornando-o de compreensão difícil. Destarte, a impetrante atribui à cláusula a tradução consentânea com a sua redação. Ora, se for o caso, isto é, se a proponente (impetrante) fosse contribuinte de tributos estaduais e municipais. Só nessa hipótese a prova de inscrição seria obrigatória. ' $E$ de outro modo não se pode interpretar a cláusula, na parte que ela própria esclarece: prova de inscrição no cadastro de contribuinte estadual e municipal, se for o caso, isto é, se for necessário, se o proponente estiver obrigado a inscrição cadastral perante as Fazendas estaduais e municipais, por ser destas contribuinte'. Tanto que, em relação ao CGC/MF, não houve qualquer dúvida e foi apresentado. (MS $5784-D F$, Relator Min. Milton Luiz Pereira, STJ) (g.n. $)^{21}$

\section{5 - Regularidade previdenciária e fundiária}

Artigo 29 - A prova de regularidade fiscal, conforme o caso, consistirá em:

IV - prova de regularidade relativo a Seguridade Social e ao Fundo de Garantia por Tempo de Serviço, demonstrando situação regular no cumprimento dos encargos sociais instituidos por lei. (redação dada pela Lei $\left.n^{\circ} 8.883 / 94\right)$

A edição de dispositivo infraconstitucional no sentido de estabelecer necessidade de regularidade perante a entidade de Seguridade Social, põe em relevo uma dificuldade que a sociedade brasileira tem em atender a ditames constitucionais.

É possível observar-se esta situação a partir da reprodução do que determina o artigo 195, parágrafo terceiro, da Constituição Federal, que assim estabelece:

artigo $195-. .$.

$\S 3^{\circ}-$ A pessoa jurídica em débito com o sistema de securidade social, como estabelecido em lei, não poderá contratar com o Poder Público nem dele receber beneficio ou incentivos fiscais ou crediticios.

Observa-se, assim, a necessidade de edição de lei ordinária determinando a observância de expresso dispositivo constitucional ressaltando-se não constitui-se tal mandamento em norma constitucional de eficácia contida, dependente de edição de legislação infra-constitucional, eis que a lei ali mencionada já se encontra editada cuidando da Regulamentação da Previdência Social. 
Reafirma tal observação, o inciso $V$ do artigo 27 da Lei $n^{\circ} 8.666 / 93$, feito inserir através a Lei $n^{\circ} 9.854 / 00$, que determina expressamente o cumprimento ao que dispõe o artigo $7^{\circ}$, XXXIII da CF, que estabelece vedação do trabalho noturno, perigoso ou insalubre a menores de 18 anos e, vedação de trabalho a menores de 16 anos.

A dificuldade de observância a expressos mandamentos constitucionais não se resume apenas nesta situação como também na própria Lei Complementar $\mathrm{n}^{\circ} 101$, de 04 de maio de 2000, a Lei de Responsabilidade Fiscal, que permite concluir como é difícil cumprir a Constituição. É necessário lei para determinar o cumprimento da Constituição, vide a Lei de Responsabilidade Fiscal que, dos 75 artigos, 14 determinam o cumprimento de mandamentos constitucionais.

Também é de se salientar a desnecessidade de inserção no Estatuto das Licitaçōes de obrigação de regularidade perante ao Fundo de Garantia por Tempo de Serviço eis que, a Lei $n^{\circ} 8.036 / 90$, que estabelece o Regulamento do FGTS, textualmente estabelece:

Art. 44. A apresentação do Certificado de Regularidade do FGTS é obrigatória para:

I - habilitação em licitação promovida por órgãos da Administração Pública direta, indireta ou fundacional e por empresas controladas direta ou indiretamente pela União, pelos Estados, pelo Distrito Federal e pelos Municipios;(g. n.)

Ora, ante ao expressamente determinado na Lei de Introdução ao Código Civil, em seu artigo $3^{\circ}$, "ninguém se escusa de cumprir a lei, alegando que não a conhece", fica por demais evidente a total desnecessidade de edição de lei, no caso a Lei $n^{\circ}$ 8.883/94, para determinar o cumprimento da Constituição e do artigo 44 da Lei $8.036 / 90$.

No sentido de observância a necessidade de regularidade perante a Seguridade Social e ao FGTS, o Tribunal de Justiça de São Paulo assim decidiu:

Mandado de Segurança - Licitação - Carta Convite - Se a impetrante não cumpriu exigência do edital, que no caso é a própria carta convite, deixando de apresentar certidão negativa municipal 'e de inexistência de débito junto ao INSS, tinha mesmo de ser inabilitada para o certame, como ocorreu'. Se a exigência é legal e geral, não pode a impetrante ser beneficiada com a dispensa, caso em que haveria favorecimento pessoal e ofensa aos princípios do artigo 37 da Constituição da República. Sentença de denegação mantida. Recurso não 'provido' (Ap. 270.927.1 - Rel. Dês. Felipe Ferreira - TJSP) $(\text { g.n. })^{22}$ 
BASTOS Celso Ribeiro. Curso de Direito Administrativo, $3^{2}$ ed., Saraiva, 1999. BOBBIO, Norberto. Estado, Governo, Sociedade - Para uma Teoria Geral da Política, Paz e Terra S. A, São Paulo, 1987.

BRITO, Edvaldo. A Constituição Brasileira de 1988 - Interpretações, Forense Universitária, São Paulo.

CASTRO, José Nilo de. Direito Municipal, Del Rey, Belo Horizonte, s.d.

CASTRO, Tupinambá Miguel. Da Tributação e do Orçamento Público, Aide, Rio de Janeiro, 1989.

CHALITA, Gabriel. Ética dos Governantes e dos Governados, Max Limonad, São Paulo, 1999. . O Poder, $2^{\text {a }}$ ed., Saraiva, São Paulo, 1999.

CIRNE LIMA, Ruy. Princípios de Direito Administrativo, RT, São Paulo, 1987.

CITADINI, Antonio Roque. Comentários sobre a Lei de Licitações Públicas, Max Limonad, São Paulo, 1996.

DALARI, Dalmo de Abreu. Elementos de Teoria Gerais do Estado, $20^{a}$ ed., Saraiva, São Paulo, 1998.

DI PIETRO, Maria Sylvia Zanella. Direito Administrativo, $1^{a}$ edição, Atlas, 2.003. 1991.

FERRAZ JR., Tércio Sampaio. Introdução ao Estudo do Direito, Atlas, 1988.

FIGUEIREDO, Lúcia Valle. Curso de Direito Administrativo, $6^{\mathbf{a}}$ edição, Malheiros, 2.003 .

FIGUEIREDO, Marcelo. Probidade Administrativa, Malheiros, São Paulo, 1995.

FRANCO SOBRINHO, Manoel de Oliveira. Ato Administrativo, Saraiva, São Paulo, 1980.

GASPARINI, Diógenes. Direito Administrativo, $8^{a}$ ed., Saraiva, 2003.

MARTINS JR., Wallace Paiva. Probidade Administrativa, Saraiva, São Paulo, 2001.

MACHADO JR., J. Teixeira. A Lei $n^{\circ} 4320$ Comentada, $30^{\mathrm{a}}$ ed., Ibam, Rio de Janeiro, 2000/2001.

MEDAUAR, Odete. Controle da Administração Pública, RT, 1993.

MEIRELLES Hely Lopes. Direito Administrativo Brasileiro, $28^{\mathrm{a}}$ ed., Malheiros, 2003.

. Direito Municipal Brasileiro, $3^{\mathrm{a}}$ ed., RT, São Paulo.

MELLO, Celso Antonio Bandeira de. Curso de Direito Administrativo, $15^{\mathrm{a}}$ ed., Malheiros, 2.003.

MORAES, Alexandre de. Direito Constitucional, $8^{\mathrm{a}}$ ed., Atlas, São Paulo, 2000.

MOREIRA NETO Diogo de Figueiredo. Curso de Direito Administrativo, Forense, Rio de Janeiro, 1996.

NUNES, Luiz Antonio. A Lei, o Poder e os Regimes Democráticos, RT, 1991.

OLIVEIRA, Austen da Silva e outros. O Município e a Lei de Responsabilidade Fiscal, Conam, São Paulo, 2000.

OLIVEIRA, Régis Fernandes de. Ato Administrativo, RT, São Paulo, 1978. 
PALAVÉRI, Marcelo. Municípios e Licitações Públicas, Ed. Juarez de Oliveira, São Paulo, 2003.

PAZZAGLINI FILHO, Marino et all. Improbidade Administrativa - Aspectos Juridicos da Defesa do Patrimônio Público, 4ª ed., Atlas, São Paulo, 1999.

REVISTA DE DIREITO ADMINISTRATIVO. Fundação Getúlio Vargas, Renovar, abr/jun, 2000, v. 220.

ROCHA, Cármem Lucia Antunes. Princípios Constitucionais da Administração Pública, Del Rey, Belo Horizonte, 1994.

SILVA, José Afonso da. Aplicabilidade das Normas Constitucionais, $3^{\mathbf{a}}$ ed., Malheiros, 1999.

SUNDFELD, Carlos Ari. Fundamentos de Direito Público, $3^{2}$ ed., Malheiros, 1997.

TÁCITO, Caio. A Inexistência dos Motivos nos Atos Administrativos, RDA, 36/78.

TEMER, Michel. Elementos de Direito Constitucional, 12ª ed., Malheiros, São Paulo, 1996. 


\section{Direito da Cidade}

Joaquim Castro Aguiar

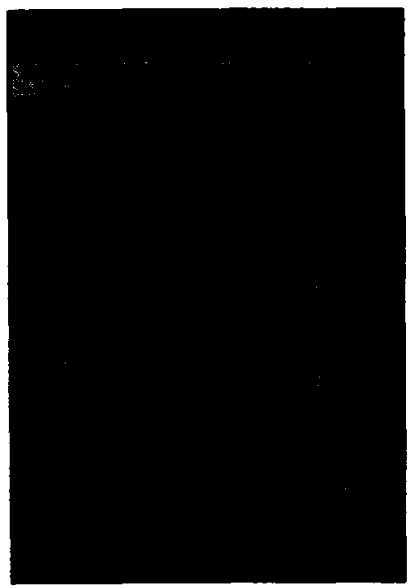

Obra útil para estudiosos dos problemas urbanos, envolvendo análise de temas palpitantes do direito municipal, tais como a função social da propriedade urbana, a repartição constitucional das competencias nessa matéria, o planejamento urbano, o plano diretor do Município, o parcelamento do solo urbano, o uso e ocupação do solo e o poder de polícia urbanística.

Ref. 0125

Form. 14x21

Brochura

1996

264 págs.

\section{Direito da Criança e do Adolescente Uma Proposta Interdisciplinar}

Tania da Silva Pereira

Esta obra surge como importante contribuiçāo ao estudo e à pesquisa do fenômeno social da infância, sendo indispensável aos profissionais que atuam ou não na área. Trabalho sério e profundo, este livro será consulta obrigatória do jurista e experto, sempre que se envolverem com o tema dos direitos da infância e da juventude.

Ref. 0114

Form. 16x23
Encadernado 736 págs. 1996

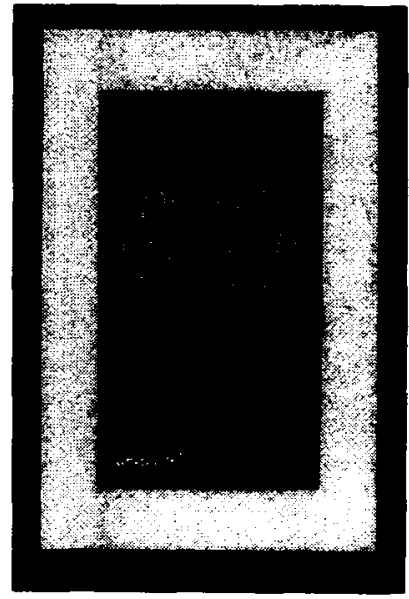

